\title{
Foreword
}

As this journal goes to press, clinicians in England and Wales face the most rapidly changing and challenging set of circumstances in the short history of clinical legal education in this country. Within a very short period of time (probably less than two years) two radical changes will have occurred. First, our undergraduate students will be expected to meet virtually the full economic cost of their education with the advent of the new tuition fees regime. Second, the current government will have sought to radically reform legal aid with the intention of reducing the legal aid budget by $£ 315$ million by $2014-15^{1}$ and at the same time, significant reductions in government spending will reduce the provision by other legal advice centres, such as the Citizens Advice Bureau ${ }^{2}$.

This being the International Journal of Clinical Legal Education, some may query the focus of this editorial on such a parochial issue. In fact, in deciding whether these changes should encourage clinicians in this jurisdiction to change their practice, and the direction of any such change, it would be wise for us to look at the range of experience internationally. Many of those jurisdictions have long had less, often far less, generous legal aid schemes and/or a requirement that students fund most or all of the fees for their tuition. In contrast to this country, in several jurisdictions, the legal aid that is available has been channelled to a certain extent through university legal clinics. Experience in other jurisdictions may well indicate the trajectory of travel for clinic in this country.

In England and Wales, there has been a growing movement in recent years to provide pro bono advice as part of legal training ${ }^{3}$. Many postgraduate professional training courses offer pro bono advice usually as a part of additional activities that students can undertake beyond their studies. Those programmes tend to emphasise that they exist both to improve the student educational experience and to, for example, "benefit members of the community who might otherwise not have access to legal services."4

However, while some law schools (one of the longest running being the University of Canterbury at Kent) place significant emphasis on providing legal advice for those who cannot afford it alongside providing a learning experience, others, such as here at Northumbria University have

1 Proposals for the Reform of Legal Aid in England and Wales Consultation Paper CP12/10, (The Stationary Office, Norwich, November 2010) Cm 7967 accessed at http://www.justice.gov.uk/consultations/docs/legalaid-reform-consultation.pdf 24.3.11

2 The CAB chief executive Gillian Guy was reported as warning of a $45 \%$ drop in $\mathrm{CAB}$ funding: Labour criticizes $\mathrm{CAB}$ funding cuts,

http://news.bbc.co.uk/democracylive/hi/house_of_1 ords/newsid_9389000/9389960.stm accessed at 25.3.11. In 2009-10 CABs provided help to 2.1 million people in solving 7.1 million problems, http://www.citizensadvice.org.uk/index/aboutus.htm accessed at 25.3.11.
3 The number of Law Schools with pro bono programmes in England and Wales rose from 33\% to $65 \%$ of all schools from 2006-2010: Grimes, R and Curtis M, Law Works Student Pro Bono Report 2011, (Law Works, 2011). The report reviews the provision of all forms of pro bono assistance by students, not just clinics. In fact, according to the report, only $50 \%$ of those Law Schools offering pro bono to students run in house representation and/or advice clinics.

4 BPP pro bono statement http://www.bpplawschool.com/probono/BPP accessed at 3.6.11 
placed more emphasis on the student learning experience. There is no requirement for clients at Northumbria's Student Law to show that they cannot afford other types of representation. The emphasis has always been on whether the cases are of educational benefit to students. Of course, many cases are brought to the office by those who cannot find legal assistance elsewhere. Sometimes this is because legal aid, though previously well resourced, does not adequately fund that area of law (particularly for employment and welfare benefits representation or certain criminal appeals). Often it is because although the individual has means that take them out of the legal aid regime, it would not be economical for them to seek the help of a lawyer with their particular problem. This is particularly the case in civil small claims cases, criminal injuries compensation matters and some family work.

It appears that in other countries there is far more emphasis on meeting unmet need and pursuing social justice imperatives.

In the U.S. in particular, social justice was and remains at the heart of the clinical movement, even if tensions exist between that and the move toward a more professional skills oriented focus. ${ }^{5}$ Even those who place education as the first priority often recognise the "social justice mission assigned to the legal profession" "and advise that in-house clinics should respond to the legal needs of the community. ${ }^{7}$

In Australia, the trend is to establish clinics not in the law school but as part of legal aid provision or other government and community provision ${ }^{8}$ and Australian clinicians often still tend to see community service and law reform as an important element of their work ${ }^{9}$. This is contributed to by the funding by the Federal Government of clinical programmes at the universities of Monash, Griffith, Murdoch and New South Wales.

In South Africa, given the significant unmet need, all clinics either represent the disadvantaged or take on law reform or community based projects aimed at the disadvantaged. ${ }^{10}$

In Eastern Europe, much of the rise of clinics in countries such as Poland has been fuelled by the desire to meet unmet need. The Legal Clinics Foundation requires that all clinics who seek support from it include provisions that ensure that their clients are unable to afford legal advice elsewhere. ${ }^{11}$ One of the key reasons why there is less emphasis on pursuing a social justice agenda in England and Wales is that legal aid as part of the welfare state has long provided for many of the most crucial aspects of work with disadvantaged groups. While financial eligibility and scope have reduced over time it is still the case that many of the most disadvantaged in our society have been able to secure legal assistance and representation. There was a strong feeling amongst many clinicians that clinic should not attempt to provide for unmet need where that need should be met

5 See for example Bloch F, Prasad M, Institutionalising a social justice mission for clinical legal education: cross-national currents from India and the United States, 13 Clinical L. Rev 2006-2007 166

6 Stuckey R, et al Best Practices in Legal Education, (Clinical Legal Education Association, 2007) 145

7 Ibid

8 Giddings, J Contemplating the Future of Clinical Legal Education Clinical Legal Education Symposium 17 Griffith L. Rev. (2008), p 3
9 Ibid. P 9

10 Maisel, P Expanding and Sustaining Clinical Legal Education in Developing Countries: What We Can Learn from South Africa 30 Fordham Int'l L.J. (2006-2007) 378

11 Krasnicka, I, Legal Education and Clinical Legal Education in Poland, 13 Int'l J. Clinical Legal Educ. (2008) 47, 53-54 
by the state ${ }^{12}$. Those assumptions about the level of support the state should offer are however being swept away.

The coalition government's reforms ${ }^{13}$ threaten access to justice by the removal of legal aid in the following areas, amongst others:

- Most claims involving clinical negligence

- Most cases involving debt other than those in which the individual's home is at immediate risk Most disputes involving the family other than those which involve domestic violence - though a small level of legal aid will be available to attempt to mediate such disputes

- All education cases, including advice on special educational needs

- Most housing cases other than those involving repossession proceedings, serious disrepair affecting health and homelessness

- Most non-detention immigration cases

- Most legal aid in welfare benefits disputes

In its response to the government's proposals the Law Society of England and Wales states ${ }^{14}$ :

If it proceeds with the proposed cuts, the Government runs the risk of reduced social cohesion, increased criminality, reduced business and economic efficiency, and increased resource costs and transfer payments for other Government departments.

These radical reforms pose a challenge to clinicians and universities in this jurisdiction. Should those clinics that currently do not have an overtly social justice agenda, incorporate such a mission, if not as a primary goal then at least as an important secondary one ${ }^{15}$ ? Additionally, do all clinics need to reassess the areas of law in which they work to maximise the impact that students can have when working on cases? Currently clinics tend to concentrate on areas not met by legal aid. The question is whether clinics need to look to prioritise the areas outlined above. Areas which the government has decided are no longer of sufficient priority in our financial climate but which arguably are of more importance to those concerned than the areas currently undertaken by clinics.

12 That concern has recently been mirrored in the profession more generally: Is the legal profession being unwittingly manoeuvred into establishing a de facto safety net? Law Society Gazette comment (14th April 2011).

13 Footnote 1 above

14 Green Paper proposals for the reform of legal aid In England and Wales Law Society response, (The Law Society, February 2011)

http:/www.lawsociety.org.uk/influencinglaw/policyi nresponse/view $=$ article.law?DOCUMENTID $=434$ 634 accessed at 25.3.11.

15 Many would argue that a social justice dimension is necessary not only to assist those in need now but equally or more importantly to educate future lawyers about the realities of the law in action and to encourage them to include pro bono service and law reform in their later professional lives. See for example Barry, $\mathrm{M}$ et al, Clinical legal education for this millennium, the third wave, 7 Clinical L. Rev. 1 2000-20011. 
A variety of counter arguments can be ranged against this call to pursue a more coordinated and overt social justice agenda. The first is that clinics cannot hope to replace the services that are lost. Ministry of Justice figures indicate that 502,000 fewer people will be assisted when legal aid reforms take place ${ }^{16}$. Northumbria's Student Law Office is a large law clinic. In 2009-10 it dealt with 358 cases as open client files. Clearly the yawning chasm which will open up in the provision of legal services cannot be filled by clinics.

There are also powerful arguments concerning the tension between education and providing access to justice. As noted above, undergraduate law students in England and Wales are about to see their fees rise from just over $£ 3000$ per annum to as much as $£ 9000$. Some students will now be meeting virtually the full economic cost of their education (albeit via a student loans scheme). In that climate, it may be even more difficult to persuade students that part of their mission as clinic students is to provide access to justice to those less fortunate than themselves. It might also be argued that while at Northumbria there is no overt social justice mission, the concentration on professional education, with clinic as a compulsory, heavily weighted module has seen more practical help given to members of the public than at universities where clinic is a voluntary noncredit bearing module albeit with a more overt social justice mission ${ }^{17}$.

Some would also argue that if the overriding goal is not education, then the student experience will suffer. If clinics were to pursue the goal of helping those most in need they might attempt to develop a model in which students deal with a large number of similar cases with minimal supervision in an attempt to help as many as possible. Students would lose the benefit of careful supervision and guidance, of time to reflect on their learning in a rush to provide volume legal advice.

For clinicians in this jurisdiction it is surely right that there is at least a debate about the place of social justice in their mission. Few would insist that clinics should do their utmost to provide legal services to the greatest number possible and to the disadvantage of their students' education. However, if one analysed the most pressing unmet need in one's area and determined that destitute asylum seekers and those refused basic welfare benefits were those most in need of assistance should the clinic continue to work on small claims civil cases? There might be good reasons to do so. Perhaps those cases prepare the students best for practice. Perhaps the clinic supervisors cannot develop expertise in these other areas. If, however, the only reason for not repositioning the clinic's work is truly that the clinic has failed to assess what might be necessary or consider the educational costs and benefits then that position is open to criticism.

16 Cumulative Legal Aid Reform Proposals, Ministry of Justice, http://www.justice.gov.uk/consultations/legal-aidreform-151110.htm accessed at 25.3.11. The Legal Action Group queries these figures and calculates that over 650,000 people will no longer have their cases funded http://legalactiongroupnews.blogspot.com/ accessed at 25.3.11.
17 It is interesting to note that $43 \%$ of all Law Schools offering pro bono activity in 2010 did not allocate any staff teaching time to it. Only $5 \%$ of all Law Schools have compulsory pro bono activity and only $10 \%$ assess student performance. Law Works Student Pro Bono Report 2011, footnote 3 above. 
Several years ago my firm meeting at Northumbria was attended by lawyers from Estonia involved in their country's nascent legal aid provision. They listened to a debate between me and my students over an interesting package travel claim on behalf of two clients who had taken a holiday in France. After the firm meeting our visitors expressed their amazement to me that we would consider taking such a case, that in Estonia there were far more pressing matters for the clinic to be dealing with. I replied that we were currently dealing with other cases of more pressing importance to disadvantaged clients but that legal aid, to a large extent, ensured access to justice in most cases. In the future that will no longer be the case and clinicians need to decide how to react to that change.

\section{In this edition}

Several of the articles in this edition directly address the social justice and/or educational agenda. Professors Lasky and Nazeri, describe the movement in Malaysia and Southeast Asia generally towards an expansion of clinic and community based legal education with a strong social justice and educational agenda. Their article gives an interesting account of the developments particularly in Malaysia of both in-house clinics and community based legal education.

In 'Bridging the Academic/Vocational Divide: the Creation of a Law Clinic in an Academic Law School,' Frank Dignan provides an insight into the process of developing a law clinic at Hull University as part of the undergraduate programme. His article indicates an approach which put the legal needs of the local community at the centre of the clinic's raison d'etre and is an example of how other providers of community advice can be involved in helping to set the clinic's objectives.

'Clinic and the Wider Curriculum,' looks to a future in which clinic is more pervasive throughout the teaching of law. Kevin Kerrigan and I argue that an integrated curriculum would invigorate the teaching of law and increase student engagement and deepen understanding. The article gives examples of simulated and real experience through which students might learn traditional substantive legal subjects. It particularly argues that real experience should not be limited to the final year of education in a clinic. This article was written before the legal aid changes that are outlined above and is perhaps an example of a tradition on focusing upon educational objectives rather than social justice ones.

In 'Walking on two legs in Chinese Law schools,' Professor Landsberg gives a fascinating insight into the US "Educate the educators" programme in China. The programme was designed to enable Chinese Law schools to successfully use experiential teaching. The article highlights the significant legal, political, structural and cultural differences between the two countries. It contains many lessons learned not only by the Chinese academy but also the Americans involved. In an echo of the article by Kevin Kerrigan and myself it is interesting to note that Professor Landsberg queries whether the US should have separated clinic from the teaching of doctrinal subjects and whether China has the greater potential to fully integrate clinic and experiential methods. 
Frances Gibson's article on the 'Convention on the Rights of Persons with Disabilities: The Response of Clinic,' investigates both how clinics should be focused on achieving access to the clinic for staff and students with disabilities and improving access to justice for those with disability. The guidelines proposed for clinics include a plan of action for ensuring that clinics themselves make proper adjustment for student disability. It is a reminder of the power of clinic to enhance the lives and prospects of its students as well as the community it seeks to serve.

\section{Jonny Hall,}

Deputy Editor 